\title{
IMPLICAÇÕES PARA A CONSERVAÇÃO DO GUAJA-DO-ARARIPE KINGSLEYA ATTENBOROUGHI (BRACHYURA: PSEUDOTHELPHUSIDAE) EM UMA UNIDADE DE CONSERVAÇÃO DO NORTESTE DO BRASIL
}

\author{
Lucena, I.C. ${ }^{1,}$; Correia, D.B. ${ }^{2}$; Landim, H.S. ${ }^{2}$; Lima, L.S. ${ }^{2}$; Pitombeira, G.S.G.N. ${ }^{2}$; Correia, D.B. ${ }^{2}$; \\ Silva, A.L.L. ${ }^{2}$; Araújo, J.G. ${ }^{2}$; Nascimento, W.M. ${ }^{2}$ \& Pinheiro, A.P. $^{2}$ \\ ${ }^{1}$ Universidade Federal do Ceará (UFC), Campus Pici, Laboratório de Zoologia Experimental. \\ ${ }^{2}$ Universidade Regional do Cariri (URCA), Campus Crato, Laboratório de Crustáceos do Semiárido. \\ *Autor correspondente: isislucena@gmail.com
}

\begin{abstract}
O Guaja do Araripe Kingsleya attenboroughi é uma espécie endêmica da Área de Proteção Ambiental Chapada do Araripe e já foi descoberta em risco significativo de extinção por ocorrer em áreas semiurbanas, onde ocorre expressiva atividade agropecuária e agrícola. O trabalho objetiva elencar os problemas observados nas áreas em que a espécie habita, como também caracterizar os mesmos segundo os residentes das áreas estudadas. Para levantamento dos dados foram realizadas aplicações de questionários semiestruturados aos moradores de duas comunidades tradicionais inseridas dentro da APA-Araripe, com perguntas acerca dos principais problemas que podem estar afetando negativamente a espécie. O trabalho foi realizado entre os meses de abril e maio de 2018 e contou com a participação de 52 entrevistados. Quando questionados quais os problemas que ameaçam a existência da espécie na localidade, 32\% afirmaram que a poluição da água e o desvio da mesma são os principais fatores que podem causar a degradação do ambiente onde vive a espécie, seguido de $14 \%$ que apontaram para o desmatamento da mata ciliar do rio, $6 \%$ para a predação por outros animais, $29 \%$ declararam ser culpa do ser humano e $19 \%$ não souberam responder. Segundo os moradores, os problemas ocorrem devido à falta de fiscalização dos órgãos que são responsáveis por gerir a área. A população reconhece sérios problemas que ameaçam a espécie, demonstrando uma percepção dos impactos no ambiente em que vivem.
\end{abstract}

Palavras-chave: etnoconservação, APA-Araripe, conhecimento popular. 